\title{
The Role of Space and Time Use Behaviors in Shaping the Incivility Experience of Young People ${ }^{1}$
}

\author{
Mekan ve Zaman Kullanım Davranışlarının Gençlerin Medeni Olmayan \\ Davranışları Deneyimlemesindeki Rolü
}

\author{
Güliz MUĞAN
}

ABSTRACT

Space can be considered as one of the important qualitative determinants of time-use. In this study, it is aimed to deal with the complex interactions between space and time-use through a survey on the urban youth in Ankara. This study also aims to underline the impact of space and time dimensions on the way that urban youth perceive and experience incivilities. The issue of (in)civility was analyzed with the help of experiences and perceptions of young people on a street. Sakarya Street, which has been a pedestrian area for 40 years, was selected as the case of this research. The field survey combined observations and interviews with a sample of 82 young people. The role of time/space interaction on uncivil behaviors was analyzed considering variations of daily and seasonal use of time. The qualitative evaluation, which was supported by statistical analyses, indicated that the physical and social environments of the street context and young people's relationships with that context are influential on their patterns of street use and time use behaviors as well as perception and experience of incivility. It was found that Sakarya was attributed as more dangerous, terrifying, unsafe and avoidable place during evenings and nights due to its deserted appearance, reduced visibility and presence of unconforming groups of individuals. Furthermore, gender differences among urban youth seemed to be influential on attributing evening and nights as more dangerous and avoidable time periods.

Keywords: incivility; Space; street; time-use; urban youth.

ÖZ

Mekân, zaman kullanımının niteliksel anlamdaki önemli belirleyicilerinden kabul edilir. Bu çalışmada, zaman ve mekân arasındaki karmaşık ilişkinin, Ankara'daki kentli gençlerle yapılan bir araştırma yoluyla incelenmesi hedeflenmiştir. Bunun yanı sıra, bu çalışma, zaman ve mekân boyutlarının kentli gençlerin medeni olmayan davranışları algılama ve deneyimlemeleri üzerindeki etkisinin de altını çizmeyi hedefler. Medeni olmayan davranışlar gençlerin sokaktaki algıları ve deneyimleri üzerinden incelenmiştir. Yaklaşık 40 yıldır yaya bölgesi olan Sakarya Caddesi, çalışma sahası olarak belirlenmiştir. Araştırma, gözlem ve 82 kentli gençle yapılan yüz yüze görüşmelerin verilerinden faydalanmıştır. Zaman/mekân etkileşiminin medeni olmayan davranışlar üzerindeki etkisi günün farklı saatleri ve mevsimsel farklılıklar çerçevesinde incelenmiştir. İstatiksel analizlerle desteklenen niteliksel değerlendirme sonucu, sokağın fiziksel ve sosyal çevresinin ve gençlerin bu çevrelerle olan ilişkilerinin, gençlerin sokak kullanım ve zaman kullanım davranışlarıyla, medeni olmayan davranışları algı ve deneyimleri üzerinde etkili olduğunu göstermiştir. Gençler tarafından, Sakarya Caddesi'nin, akşam ve gece saatlerinde rahatsız edici insan gruplarının varlığı sebebiyle daha tehlikeli, korkutucu, tekinsiz ve uzak durulması gereken bir mekân olduğu belirtilmiştir. Ayrıca, bu tespitin gençlerin cinsiyetine göre farklılaştığı da gözlemlenmiştir.

Anahtar sözcükler: Medeni olmayan davranışlar; mekân; sokak; zaman kullanımı; kentli gençler.

'Some parts of the study was used as a presentation within the context of $31^{\text {st }}$ Conference of the International Association for Time Use Research, In Leuphana University Lüneburg, Germany, in 23-25 Sepetember 2009.

Department of Interior Architecture, Okan University Faculty of Art, Design and Architecture, İstanbul, Turkey

Article arrival date: January 12, 2017 - Accepted for publication: January 28, 2018

Correspondence: Güliz MUĞAN. e-mail: guliz.mugan@okan.edu.tr

๑ 2018 Yıldız Teknik Üniversitesi Mimarlık Fakültesi - ๑ 2018 Yıldız Technical University, Faculty of Architecture 


\section{Introduction}

In contemporary urban context, there seems to be a growing interest in studying (in)civility due to an increasing concern about dangerous and disordered image of city that is identified with the term incivility and anti-social behaviors among diversity of people in cities (Boyd, 2006; Eldridge, 2010; Fyfe, Bannister and Kearns, 2006; Held, 2015). Accordingly, a predominant focus in the literature becomes questioning the means that make living among strangers possible and provide a civil way of life. However, failure in the everyday encounters, including incivil relations with those unknown others has been given less attention (Philips and Smith, 2006). Therefore, incivilities resulting from daily encounters with strangers and experiences of incivility in daily life within the city context are the foci of this study.

Sennett (1996) argues that people having diverse social and political backgrounds recognized the necessity to reconstitute the city life starting with 1990s. The acceleration in the contemporary urban developments has different impacts on citizens. Urban youth is the most influenced group in the city by the contemporary urban development and transformation due to its exposure to all the innovations and changes. Moreover, young people who pass through a transitional age range, which is somewhere between childhood and adulthood, are both hopes for the future and also potential threats for the permanence and stability of the society with their disorderly, threatening and 'not approved' behaviors in the urban realm (Franzini et al., 2008). As a matter of fact, they might even mostly be seen as primary causes of fear (Cops, 2013). However, it is important to note that, young people themselves might be the main targets of incivil acts at different situations. This leads to the understanding of a contradictory position for young people as being both victims and victimizers; targets and actors of incivil acts (Cops, 2013; Pain, 2001).

As Neyzi (2001) indicated, in the media age, the link of globalization to the changing conceptions of time and space leads young people to challenge their representations and create new spaces through which they try to express their identities. Hence, how youth perceive, experience and live out changes over time with the changing expectations is an important field of research concerning the future of urban cities. Besides, as Cops (2013) pointed out concerning the fact that traditional focus in researches of fear of crime and disorder in public spaces is notably on women and elderly, young people and their perspectives are mostly neglected. Therefore, in this study, with a shift from focusing on how adults perceive incivilities and experience fear of crime in cities to the the point of view of youth' is assumed to be necessary to criticize and discuss two contradictory arguments: the assumption regarding young people 'as a group which mostly engage in incivil behaviors' and 'as the probable target group of many incivil behaviors and events' in the urban context. Moreover, the differences among urban youth are aimed to be considered by focusing on variations across gender.

Urban public spaces including parks, streets, squares and neighborhood areas are mostly mentioned together with incivility, disorder and fear of crime (see Held, 2015; Malone, 2002). This identification of incivility with certain urban public spaces is significant in terms of context dependent embodiment of incivility in the urban realm. At this point, it is crucial to underline the space dimension as an important source of incivilities. Moreover, the spatial dimension can also be linked to the incivility argument in terms of its relation to some incivilities that are resulted from space- and environment-related problems, deteriorations in physical environment and urban planning failures. Apart from this, space can be considered as one of the important qualitative determinants of time-use and time-use activities obtained through diaries could better be evaluated in their relationship with spaces (see Erkip and Mugan, 2007 for the details of the field survey in Ankara). ${ }^{2}$ In the light of all these arguments, this study aims to deal with the complex interactions between space and time-use through a survey in an urban public area of Ankara by focusing on how these interactions affect the way that urban youth perceive and experience incivilities.

\section{Incivility Experiences of Urban Youth on Streets}

Incivility and city life have been mentioned together since 19th century (Watson, 2006). This association is mostly manifested in the public spaces of the urban realm. Lieberg (1994) claims that one of the significant roles of public spaces for young people is providing the opportunity to control and shape their existence without the control of adults. In this respect, street is an important place for everyday lives of young people as a setting for the recognition of their presence in public places as well as a place designated for public gathering, entertainment and leisure. Matthews, Limb and Taylor (2000), by using the term 'street' as a metaphor for all public spaces where children and young people are seen, point out that engagement with street help young individuals to develop their own identities. However, in the literature, there are discussions which argue that the use of spaces such as streets is limited for young people in modern urban environments. For instance, Punch (2000) explains the reason of constrained use with

\footnotetext{
The first national time-use survey of Turkey was completed in 2006 by the Turkish Statistical Institute (TURKSTAT) and the results of the survey were published in 2009 (see TUIK, 2008). In the light of these arguments, Turkish application of the time-use survey seems to have important missing components, - the location of activity and the lack of qualitative analysis that could bring out subjective interpretations of people about activities and the spaces in which they take place.
} 
threatening and dangerous factors such as assault, traffic, pollution, etc. on streets. Furthermore, several scholars explain the restricted time-use of young people in outdoor environments through parental restrictions due to parents' fears of danger and incivility on streets (Vanderbeck and Johnson, 2000; Wooley, 2006) as well as young people's fear of danger (see Malone and Hasluck, 1998). Hence, the result is, as Hendry, Shucksmith, Love and Glendinning (1993) stated, although young people have more time, opportunities and less responsibility compared to adults, they are also restricted by lack of power, lack of access and by legal and parental limitations in their engagement with leisure time, activities and spaces. Thus, a progressive retreat from the street through exclusionary practices such as parental restrictions (see Jackson, 1998; Malone, 2002) and the increase in preferences of more controlled and privatized environments such as shopping malls and gated communities (see Mugan and Erkip, 2009; Staeheli and Mitchell, 2006) are observed in modern urban life.

In the Turkish context, according to ranking of major 'hang out' places where young people spend most of their time through gathering, meeting friends and engaging in various leisure activities, street follows home environments and cafés (Konrad Adenauer Foundation, 1999). In another study, which is conducted with the Turkish youth, the ranking of street among mostly preferred leisure spaces is way below some other public spaces including shopping malls, café/restaurants, friends' houses and some game-areas/saloons (billiards, computer games, etc.) respectively (Mugan and Erkip, 2009). Furthermore, according to the results of the Turkish time-use survey (TUIK, 2008), most of the leisure time of the youth who are between the ages of 15 and 24 is not significantly different from adults and is restricted to home environment and with the activities of watching TV and DVD. Besides, there seems a difference in time-use of boys and girls, which may be explained by a more strict parental control on girls in the Turkish society (see Figure 1 and Table 1).

Nevertheless, a research conducted in Turkey finds out that outdoor physical environments are crucial for the healthy development of young people and findings indicate that children mostly prefer spacious and vegetated outdoor settings, even their school yards (Ozdemir and Yilmaz, 2008). In this context, it is necessary to figure out the influence of environmental attributes of outdoor environments on the perceptions and preferences of young people in order to tackle with problems and incivilities of youth and public concern. Therefore, it seems worth of analysis to investigate the everyday encounters and activities of young people in an outdoor environment, i.e., street and to examine the way that young people perceive and experience incivility in that context.

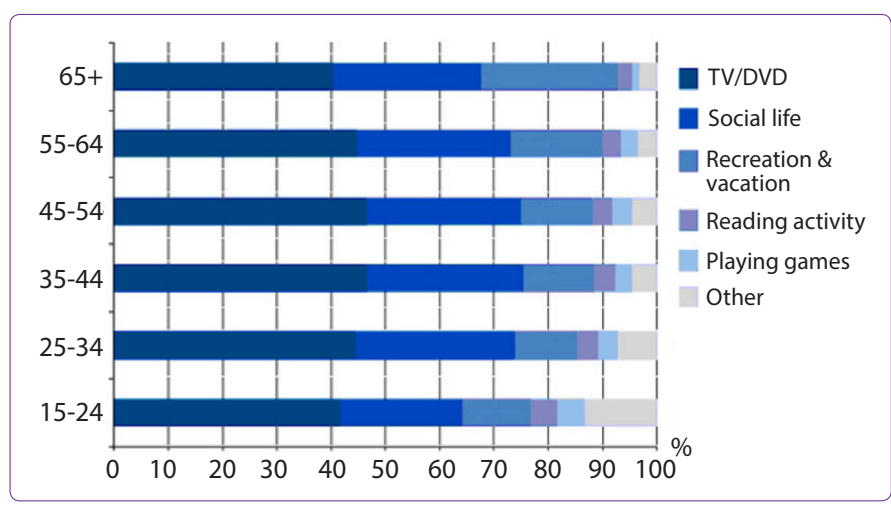

Figure 1. The distribution of time spent on leisurely activities according to age. Source: TUIK (2008), p. 26.

Table 1. The distribution of time spent on leisurely activities according to gender for the age group 15-24

\begin{tabular}{lcccc}
\hline Activity type & \multicolumn{4}{c}{ Age group } \\
\cline { 2 - 5 } & \multicolumn{4}{c}{ 15-24 } \\
\cline { 2 - 5 } & Total & Male & Female & Total \\
\hline Social life & 22.5 & 19.8 & 25.3 & 29.2 \\
Entertainment & 2.1 & 2.6 & 1.6 & 1.0 \\
Recreation and vacation & 12.7 & 13.5 & 11.8 & 11.4 \\
Physical training & 3.8 & 5.9 & 1.5 & 1.9 \\
Hunting, fisheng etc. & 0.2 & 0.4 & 0.1 & 0.1 \\
Sports & - & 0.1 & - & 10.1 \\
Arts & 0.5 & 0.3 & 0.7 & 0.2 \\
Hobbies & 3.2 & 4.2 & 2.1 & 2.4 \\
Playing games & 5.1 & 8.4 & 1.5 & 3.6 \\
Reading activity & 4.8 & 3.6 & 6.2 & 4.0 \\
TV/DVD & 41.7 & 38.7 & 44.9 & 44.7 \\
Radio/music & 3.4 & 2.6 & 4.2 & 1.4 \\
Total & 100.0 & 100.0 & 100.0 & 100.0 \\
\hline
\end{tabular}

The Impact of Time on Experience of Incivility in the Street Context

When human activities and movements are considered, it is not possible to exclude space or time dimensions. Assumptions from researches on time-geography, routine activity principles and defensible space theory underline that space-time variations are affective in activities such as crime and victimization. (Ceccato and Uittenbogaard, 2014). As it is emphasized in the previous studies, it is considered that the physical and social environments of a space and individuals' relationships with those environments in which activities take place would be influential on time use behaviors as well as space use of those individuals (see Erkip and Mugan, 2007). In addition to this, the abovementioned arguments indicate that young people's space and time use behaviors and their environmental preferences are closely connected to the perception and expe- 
rience of incivility and disorder. Moreover, Loader, Girling and Sparks (1998) state that people's sense of place and their relationship to a particular place including the spent time, the arrival and departure, etc. are influential on the identification that individuals make with fear of crime. In this respect, it is crucial to analyze the role of time/space interaction on perception and experience of incivility.

The variations in use of time in the street context are discussed as being influential on perception and experience of incivility. Especially, the impact of daily variations on fear of crime is highlighted. As Ceccato and Uiteenbogaard $(2014$, p. 133) stated "time is a both necessary condition and a constraint for any activity [and] committing a crime is just an example of these activities". In their study, which investigates daily, weekly and seasonal variations of crime in transportation nodes of Stockholm, they revealed that crimes tend to happen more often in the evening and at night, as well as on holidays and on weekends. In addition, Valentine (2001) underlines the role of night on the increase of fear of crime on streets due to the use of streets at night concerning the reduced visibility with darkness and reduced number of people on the streets and increased number of 'unknown men' (see also Çolpa, 2015 for the security problems arising from insufficient lighting on streets). Likewise, Erkip (2003) also discusses the danger of streets and urban parks at nights by underlining the threat for women and elderly. Moreover, Held (2015) in her study also explores the issue of comfort and safety in the night-time lesbian leisure spaces and she suggests that emotions such as comfort and safety can easily be threatened in night-time leisure spaces since those emotional states are gendered and sexualized. Thus, in addition to the variation in time, gender also seems to be influential on perception and experience of incivility in the street context. Accordingly, the focus of this study is to elaborate on the impact of variations in time on perception and experience of incivility in a certain space, i.e., street by concentrating on the influence of gender. This focus is assumed to provide the possibility to make a thorough discussion on the complex interaction between space and time.

\section{The Field Survey ${ }^{3}$}

According to the above-mentioned literature review, a field survey was conducted in order to figure out the impact of variations in use of time in street context by focusing on the influence of gender. Thus, the research was shaped around the question of 'how are daily and seasonal variations influential on the way that Turkish urban youth perceive and experience incivility within the context of a city street in Ankara?' (see Figure 2).

\footnotetext{
3 The field survey was designed as a part of a more comprehensive research about incivility and urban youth, which was conducted between the years 2008 and 2009 (Mugan, 2009).
}

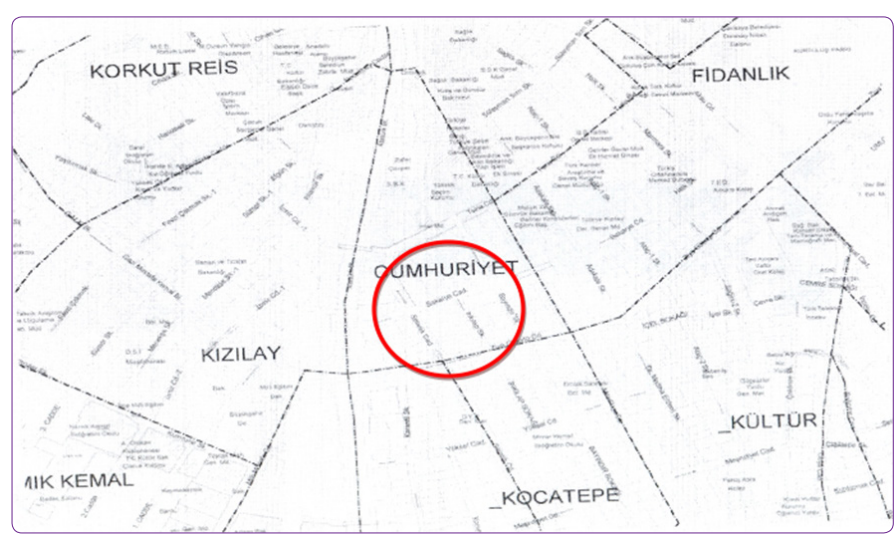

Figure 2. Location of Sakarya within the context of Ankara.

Sakarya, ${ }^{4}$ which has been a pedestrian area for almost 40 years, was selected as the case of this research due to its vivid character with entertainment and leisure spaces such as bars, cafés, restaurants and food selling kiosks. The region is in the center of Kızılay, Ankara. After the declaration of Ankara as the capital of the newly founded Turkish Republic in 1923, the Republican Regime was interested in creating new spaces that were required by the new administration and gave importance to public spaces as representative of modern cities through which the social and cultural practices of modern life style could be created and organized. Accordingly, especially in the Early Republican Period (1923-1950), Kızılay Square gained importance as a new bureaucratic and politic center which was conceived to construct a new urban life style together with houses, parks, and administrative buildings (Turhanoğlu, 2014). However, following the 1980s, where the determinant course was for consumer policy, the square became a center for car-oriented planning, which was used by civilians actively for spending time. After 1990s, many car-oriented transportation projects in the city center resulted in deterioration and degeneration of the city center as well as the changes in the user profiles of Kizılay. Only a few places such as Sakarya Street and its surroundings, Izmir Street, and Yüksel Street are pedestrian streets in Kızılay. In this context, Sakarya, located in Kızılay, has an important position within the city center, since it preserved its significant characteristic as being one of limited pedestrian streets that appealing to variety of urban people from past to present (Çolpa, 2015).

Sakarya is an important meeting place of Ankara which is full of diverse meanings for different individuals with alternative places such as public institutions, various cafes, bars, banks, florist shops, restaurants etc. In addition, it is significant in the urban public life, with its location and diversity and density of users (see Figure 3-5).

\footnotetext{
4 'Sakarya' is used to refer to the pedestrian region that constitutes a group of adjacent streets.
} 


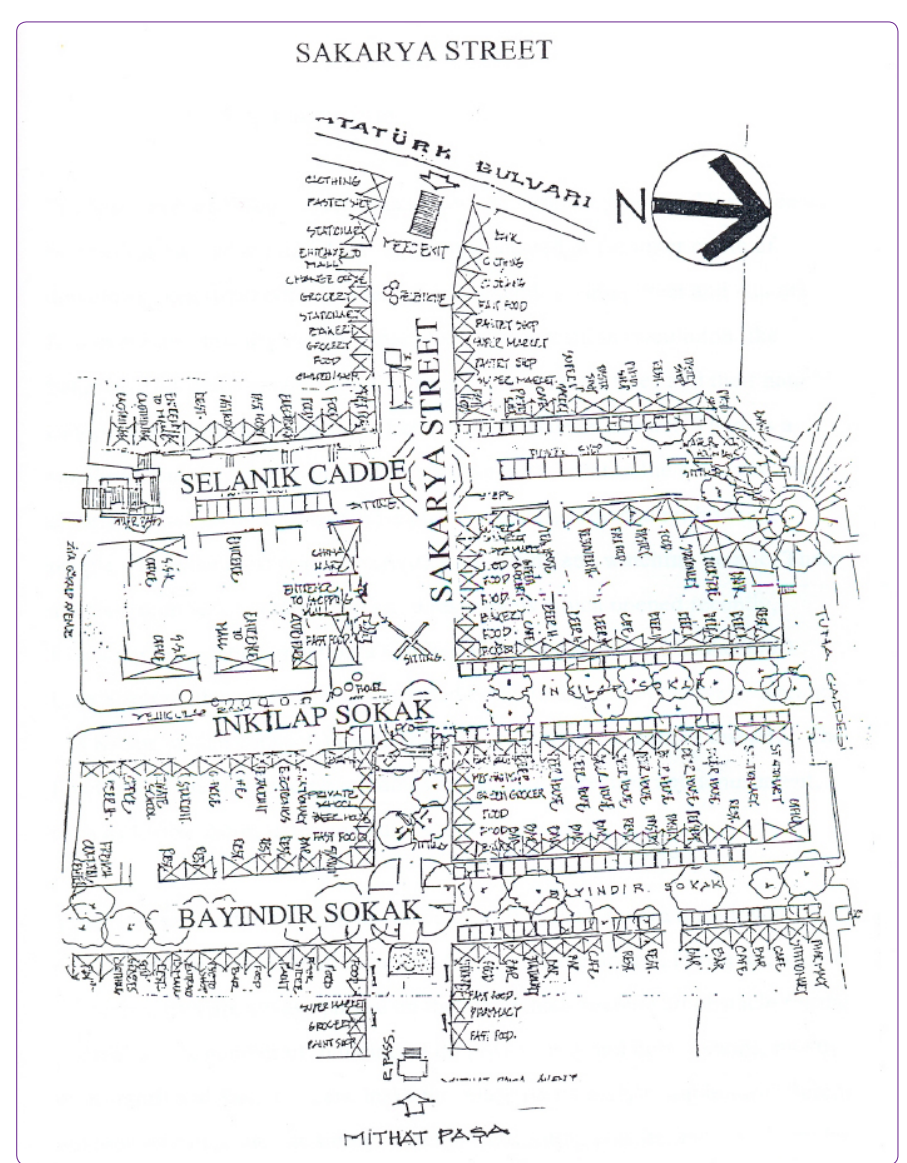

Figure 3. Sakarya as the main arterial area and its street furniture and their functional distribution on the street. Source: Mahmud (1996), p. 105.

Since it is at the center of the city, it is also at hubs of mass transport such as public buses, mini-buses, and especially subway. In this respect, Sakarya can be considered as an important node in Ankara that serves for the legibility of the city. This quality increases the efficiency of the street with its accessibility particularly for pedestrians. The changing life styles of the residents of Ankara also lead to rapid changes the dynamics of this area. Variety of activities and places in Sakarya attracts many people from different social class, age and gender groups. It is especially an attraction center for urban youth and students. For instance, pubs and clubs opened in the last decade, which are spread along the business and commercial areas and upper floors of shopping arcades, are mostly preferred places by the urban youth and turned the region into an important entertainment center of the city. Besides, many students of dershane ${ }^{5}$ located in Kızılay region, were spending time in those entertainment places in Sakarya. When the government decided to close them down in 2013, student population started to decrease in Kızılay as well. Nevertheless, due to the alternative leisure

\footnotetext{
5 Private establishents preparing students for various exams.
}

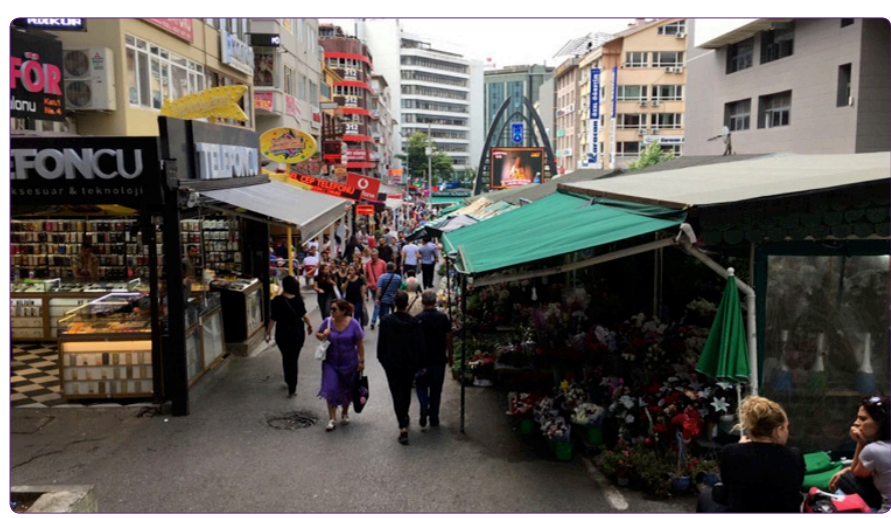

Figure 4. Crowding and variety of places and facilities in Sakarya (August, 2017).

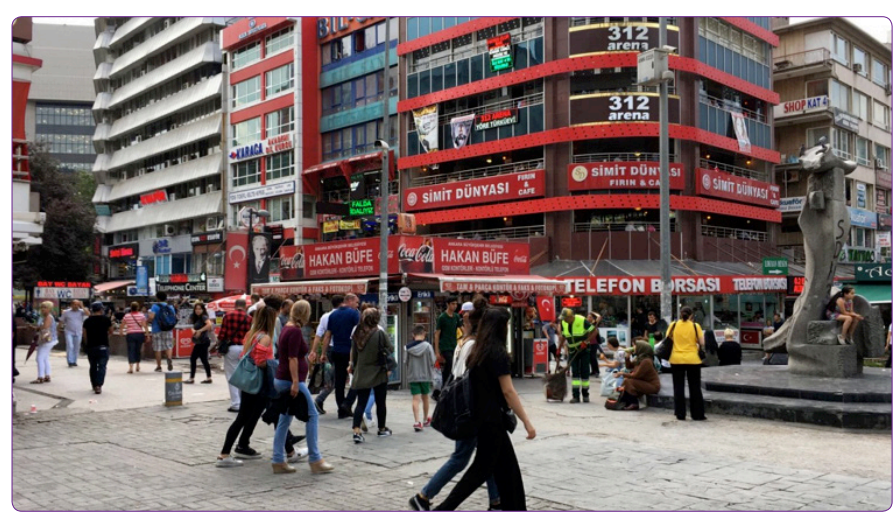

Figure 5. Diversity and density of users and facilities in Sakarya (August, 2017).

places and activities in Sakarya, it continued to be an attraction point (Çolpa, 2015).

Apart from these, the image of Sakarya among most of the citizens of Ankara is an entertainment place for the people of lower middle class (Yetkin, 2003). It is also notorious for being a place 'for easy alcohol consumption' and being 'full of criminals' where 'ordinary citizens' and families avoid entering after a certain hour. Besides, shop owners express their fears and worries regarding those dangerous individuals who are leading problems due to excess alcohol and drug use (Bayer, 2007, November 27; Zaman, 2003, May 21). Accordingly, this makes Sakarya an important site for the investigation of perceived and experienced incivilities by the urban youth.

\section{The Methods of the Survey}

Within the scope of the field survey, multiple methodological perspectives was preferred concerning the benefits of using qualitative and quantitative methods together in different steps of the research. Although quantitative and qualitative methods were used at several phases of the research process, the main aim was to collect qualitative data, so that quota and convenience sampling methods were used to select 82 young people of whom the 
age ranges were between 15 and 24 inclusive. ${ }^{6}$ Sampling quotas were identified on the basis of gender, then convenience and judgment samplings were used to select equal number of respondents for each quota (41 females and 41 males). Besides, time sampling method was used to grasp the differences in young people's patterns of street use and to investigate the impact of time variations on encountering different types of incivilities and environmental stressors. The research was conducted between the months January and June, both in week days and weekends between 10 a.m. and 12 p.m. to avoid biases of seasonal and daily patterns of use of this particular age group.

In this field survey, a semi-structured interview guide was prepared. In addition to the demographic information about the youth including their age, sex, education level and income level, young people were asked about their patterns of use of Sakarya including, familiarity and duration of use, the frequency of use, the aim of use, the mode of transportation to Sakarya, the time spent, the preferred time of use and seasonal changes in the patterns of use. Then, information about the perceived and experienced incivil behaviors/events and environmental problems that young people mostly encounter in Sakarya without underlining the observed and actual signs of incivility was collected. In addition to the interviews, actual and visible signs of disorder and incivilities were examined in the site.

Moreover, face-to-face in-depth interviews were conducted with two local government officials, one person from security staff and two bar/restaurant owners on the street as key informants to trace the problems/incivilities in Sakarya and to criticize the arguments that were brought out by young respondents.

\section{The Results and the Discussions}

\section{Patterns of Street Use and Time Use Behaviors on the Street}

As it was mentioned before, respondents' patterns of use of Sakarya and their time-use habits in the area are crucial for the analysis of incivility and environmental problems. Accordingly, more than half of the respondents claimed that they have known and used Sakarya for more than five years. When the frequency of young people's use of Sakarya was analyzed, almost half of the respondents stated that they have been using and visiting the street several times in a week. The mode of transportation that

\footnotetext{
6 Young people, who were interviewed during the time that the research was conducted, are now turning into their 30s. Therefore, throughout this manuscript, 'young people' is used by referring to 'young people of 2009'. Concerning the fact that, with changes and developments in technology and communication as well as in socio-political and socio-economic context of cities, the category of youth is also changing very fast and this point needs further and up-to-date analysis. This should be pointed out as a limitation of this research, so that the current validity of the data is aimed to be analyzed through a future research with the urban youth of this era.
}

young people preferred to use for coming to Sakarya was mostly public transportation, especially buses/mini buses. The aim of using Sakarya was mostly leisurely including the activities of meeting friends, hanging out, going to bars and drinking, enjoying diversity of cheap food choices and shopping. Weekends' afternoons and evenings as being the main leisure time for many young people, were observed as the most preferred time to use Sakarya. In addition, more than half of the respondents explained their reason of time preference with leisure purposes. Almost half of the respondents claimed that they were spending more than 3 hours in Sakarya and they stated that their aim of use was also leisurely.

For some of the respondents, the aim of using Sakarya was related to some compulsory activities that they had to engage like attending educational activities such as some private courses about computers, foreign language etc. Moreover, some of these respondents pointed out that they were simply using Sakarya since their work place was there or they had things to be done in Sakarya like going to their tailors, banks, etc. Some other respondents claimed that they were just walking through Sakarya as a transition area for another point of destination. For the rest of the young people, the aim of using Sakarya covered some compulsory and leisurely activities together. Furthermore, during the observations, it was noticed that even if they were using the district for the purpose of attending educational activities, during breaks or after those hours, Sakarya turned into a recreation area for these group of young people where they smoked, chatted with friends, ate fast food, went to bars or cafés, etc. (see Table 2 for the patterns of young people's use of Sakarya). Furthermore, respondents were asked whether the frequency and the preferred time of using Sakarya, the time spent in Sakarya and the aim of using Sakarya were changing with the seasons. According to the answers, only the frequency seemed to be influenced by seasonal changes. Even if more than half of the respondents stated that their frequency of use was not changing according to variations in season, the ones who stated they used and visited the street more frequently during spring and summer times that provide the conditions to spend time outside were close to this percentage.

\section{The Impact of Variations in Time on Perception and Experience of Incivility}

During the observations on the site, it was noticed that there were some daily and seasonal variations in Sakarya that may affect the perception and experiences of different incivilities. For instance, when it gets dark, visibility for the certain areas of Sakarya and the number of individuals on the streets decrease. Çolpa (2015), in her research, mentions that light from the shops on different 
Table 2. Patterns of Street Use and Time Use Behaviors

\begin{tabular}{|c|c|c|}
\hline & \# of Cases & $\%$ \\
\hline \multicolumn{3}{|l|}{ Familiarity and duration of use } \\
\hline For the first time & 3 & 3.7 \\
\hline Less than 6 months & 3 & 3.7 \\
\hline 6 months - 2 years & 12 & 14.6 \\
\hline 3-5 years & 20 & 24.4 \\
\hline More than 5 years & 44 & 53.7 \\
\hline Total & 82 & 100.0 \\
\hline \multicolumn{3}{|l|}{ Frequency of use } \\
\hline Everyday & 3 & 3.7 \\
\hline Several times in a week & 36 & 43.9 \\
\hline Once a week & 18 & 22.0 \\
\hline Once in two weeks & 7 & 8.5 \\
\hline Once a month & 8 & 9.8 \\
\hline Less than once a month & 4 & 4.9 \\
\hline Other & 6 & 7.3 \\
\hline Total & 82 & 100.0 \\
\hline \multicolumn{3}{|l|}{ The preferred time of use } \\
\hline Week times-morning & 5 & 2.6 \\
\hline Week times-afternoon & 25 & 13.0 \\
\hline Week times-evening & 29 & 15.1 \\
\hline Weekends-morning & 21 & 10.9 \\
\hline Weekends-afternoon & 67 & 34.9 \\
\hline Weekends-evening & 45 & 23.4 \\
\hline Total & $192 *$ & 100.0 \\
\hline \multicolumn{3}{|l|}{ The time spent } \\
\hline Less than half an hour & 4 & 4.9 \\
\hline Half an hour-1 hour & 18 & 22.0 \\
\hline $1-3$ hours & 26 & 31.7 \\
\hline More than 3 hours & 34 & 41.5 \\
\hline Total & 82 & 100.0 \\
\hline \multicolumn{3}{|l|}{ The aim of use } \\
\hline Compulsory & 20 & 24.4 \\
\hline Leisurely & 46 & 56.1 \\
\hline Both & 16 & 19.5 \\
\hline Total & 82 & 100.0 \\
\hline \multicolumn{3}{|l|}{ The mode of transportation } \\
\hline Subway & 11 & 13.4 \\
\hline By walking & 8 & 9.8 \\
\hline Bus/mini bus & 55 & 67.1 \\
\hline Car/Taxi & 8 & 9.8 \\
\hline Total & 82 & 100.0 \\
\hline
\end{tabular}

*Total of multiple counting for the preferred time of using Sakarya ${ }^{7}$

regions of Sakarya is an important source for illumination. Therefore, some security problems are resulting from insufficient lighting. She $(2015$, p. 120) continues that "when the majority of the shops are closed, the insufficiency level

Multiple counting refers to the multiple responses for a number of questions that necessitate a distinction between the number of responses and the number of people responding. increases. Policemen are rarely patrolling during the nights so the security level is decreasing [...]. On the other hand, when many delivery cars and trucks enter the street during day time, traffic safety level is decreasing".

In addition, during autumn/winter, due to the rain and snow, water accumulates on sidewalks and pavements. One of the bar owners in Sakarya brought out similar complaints regarding the relationship between variations in time and increased incivilities on the street as follows:

I think that the lighting of Sakarya is insufficient. Especially, when it gets dark, cross streets seems very deserted due to the insufficiency of lighting. As a grown up individual, it even makes me feel scared when I have to walk alone late in the night. Infrastructure is another major problem that makes the streets very messy and dirty since the unclean waters and litter accumulates on the sidewalks especially during autumn and winter when rainy days increased.

Besides, during spring and summer times, due to the warm/hot weather, Sakarya gets crowded and the number of individuals using the outside areas of the region increases. Thus, it seems to be important to question whether these variations are influential on perceptions of incivility by urban youth. In order to interpret the impact of variations of time including day and night differences and seasonal variations, young people were asked to mention whether there were any time periods in which they avoided or were reluctant to use Sakarya. According to the findings, almost $70 \%$ of the respondents answered positively by highlighting the evenings and the nights which were seen as dangerous and may lead to many incivil conducts (such as sexual and verbal harassment and burglary) due to deserted appearance of Sakarya, reduced visibility and emergence of unconforming groups of individuals including some unwanted groups of males. Besides, during the observations, it was noticed that although the number of drunks and intoxicated individuals were not very considerable during the day time, when it gets dark their number increased immensely. They use the corners of the streets and dark areas, especially exits of subway. They light a fire to get warmed and use inside of some buildings to spend the night.

When the respondents' tendency to avoid Sakarya for certain time periods (evenings and nights as it was declared) was tested along their gender, a significant relationship was observed between the tendency to avoid using Sakarya for certain time periods and the gender $\left(x^{2}=21.693, d f=1, p=.000\right)$. Confirming the previous researches which argue that streets are dangerous and fearful places for women, especially at nights (see Blöbaum and Hunecke, 2005; Erkip, 2003), the findings of the field survey also pointed out that many female respondents 
stated evenings and nights in Sakarya as the most dangerous times due to the probable encounters with drug addicts and disturbing men. One of the respondents' comments regarding the influence of evenings and nights on their perception and experience of incivility can be given as follows:

Once I had to spend a night here in Sakarya. The area becomes totally a different place at nights. Those homeless individuals start to appear. That night I understood that Sakarya is their home and I felt myself as if I entered someone else's house without permission. Inevitably, I spent that night in one of the buildings entrances with one of those guys. Fortunately, he was faint and did not even notice me. It was a terrifying experience. After that I prefer to avoid staying till late hours in Sakarya.

(21-year-old, male)

In the light of the statements of the young respondents, it is possible to argue that some perceived and experienced incivil conducts affected the feelings about and tendency of use of Sakarya at night for young people as well as for their parents. Moreover, when we conducted statistical analyses, the statements of young people about whether there are time periods in which they avoided or were reluctant to use Sakarya was observed to have a slight positive correlation with their statements about whether problems/incivilities in Sakarya affected their feelings and their tendency of approach to the district $(r=0.293 \mathrm{df}=80, p<0.01)$. However, one of the local government officials, by criticizing the bar owners, who give permission to the entrance of young people who are under the age of 18, and irresponsible parents, who let their children to a place where lots of bars are located, argues that it is possible to see lots of young people in Sakarya even after midnight.

The respondents were also asked about whether the problems/incivilities that they had indicated varied according to the seasons. During the interviews, which were conducted at three different seasons (winter, spring and beginning of summer), it was not observed any notable differences in the responses that was expected to show variations according to seasons. According to the findings, it was seen that a few of the respondents mentioned that seasonal variations were influential on the problems/incivilities. In addition, according to $94 \%$ of the respondents, season does not affect the things that they disliked in Sakarya. However, it was observed that all 5 respondents who declared that the things that they disliked in Sakarya changed according to seasons were females. In other words, a significant relationship was obtained with the statements about the impact of seasonal variations on the things that the young people disliked in Sakarya and their gender $\left(\chi^{2}=5.325, d f=1, p=.021\right)$.
As Robin, Police and Couty (2007) stated, women perceive more environmental annoyances with high scores of stress regarding environmental concern. Consistent with this argument, according to the female respondents, the impact of seasonal variation was explained in terms of increased environmental pollution during summers due to increased number of users in Sakarya. Besides, one of the respondents highlighted the negative influence of winter on the streets due to the accumulation of muddy water between the broken parts of pavements and sidewalks.

I think in the winter, Sakarya appears to be more dirty and polluted due to muddy water of rain and snow. Since the pavements and sidewalks are broken and distorted that muddy water is accumulated between the broken parts. I hate walking on the streets during the winter time since my boots get muddy.

(17-year-old, female)

In addition to the explanations for the impact of seasons on emergence and intensity of environmental pollution on the streets, increased number of unconforming individuals and intensified sexual and verbal harassment during summer times were also highlighted by the female respondents as the impact of season.

The environmental pollution increases with crowds coming to Sakarya in summers. During summer time people prefer to sit and eat at the outside and therefore litters and trash on the sidewalks are increasing.

(22-year-old, female)

The number of criminal acts such as sexual and verbal harassment or hit-and-run attacks increases in summer times due to the good weather that leads to increased number of individuals in Sakarya.

(17-year-old, female)

To sum up, the variations in the time of the day seemed to influence the most of the young people's perception and experiences of incivility: during evenings and nights, Sakarya was attributed as more dangerous and terrifying. However, the impact of seasonal variations on the perceptions and experiences of incivility seemed to be underestimated by young people.

\section{Concluding Remarks}

The qualitative evaluation, which was supported by statistical analyses, indicated that the physical and social environments of the street context are influential on youth's patterns of street use and time use behaviors as well as perception and experience of incivility. Accordingly, different groups of urban youth having different sense of place were observed to attribute different meanings to Sakarya concerning their time use and space use behaviors. For some of them, Sakarya is a leisure place where they feel 
secure and independent, for some others, it is a dangerous place that they have to avoid as much as possible and for some others, it is a place which they have to pass through as a transit path or have to go for some compulsory activities such as attending some educational facilities. Moreover, according to the findings, patterns of street use seemed to be somehow related to young people's perception and experience of Sakarya as problematic, incivil and unsafe place as it was expected.

Concerning the impact of daily and seasonal variations on the perception and experience of incivility within the street context, it was found that Sakarya was attributed as more dangerous, terrifying, unsafe and avoidable place during evenings and nights due to its deserted appearance, reduced visibility and presence of unconforming groups of individuals which confirms the results of previous studies discussed in the literature (see Ceccato and Uittenbogaard, 2014; Çolpa, 2015; Erkip, 2003). In addition, variations in time of the day appeared to be influential on the feelings about and tendency of street use. Moreover, parental restrictions on youth in terms of using Sakarya was declared to be more predominant for evenings and nights regarding parents' fear of increased potential dangers and threats when it gets dark. Yet, the impact of seasonal variations was not confirmed even though the experience of some incivilities was affected by weather conditions.

Furthermore, gender differences among urban youth seemed to be influential on attributing evening and nights as more dangerous and avoidable time periods for Sakarya. The findings indicated that many female respondents, compared to very limited number of male respondents, underlined the impact of daily and seasonal variation on perceived and experienced incivilities by highlighting sexual and verbal harassment against females.

To sum up, this study provided an empirical basis for the discussion about the role of space-time dynamics on perception of incivility. Differences in patterns of street use of urban youth seemed to be inter-dependent on their time use behaviors and activities, which means that any kind of behavioral analysis for any social category should be constructed around the questions of 'where?' and 'when?'. Hence, the missing component - the location of activity in researches such as time-use surveys becomes inevitable to be included.

This case focused on urban youth and showed that time and space use is interrelated in a way that one defines the other. Thus, similar case studies on the characteristics of different groups of people have a great potential to test the data gathered in time-use surveys.

\section{References}

Bayer, Y. (2007, November 27). "Sakarya Caddesi haydut yatağı oldu." Hürriyet. [On-line] Available: <http://hurarsiv.hurriyet. com.tr/goster/haber.aspx?id=7764611\&yazarid=42>

Blöbaum, A. \& Hunecke, M. (2005). "Perceived danger in urban space: The impacts of physical features and personal factors." Environment and Behavior, 37 (4), 465-486.

Ceccato, V. \& Uittenbogaard, A. C. (2014). "Space-time dynamics of crime in transport nodes." Annals of the Association of American Geographers, 104 (1), 131-150.

Cops, D. (2013). "The role of autonomous mobility in public space on fear of crime among adolescents." Journal of Youth Studies, 16 (8), 1105-1122.

Çolpa, Z. M. (2015). Convivial urban spaces: The case of Sakarya Street, Ankara. (Unpublished Master Thesis). Ankara: METU.

Eldridge, A. (2010). "Public panics: Problematic bodies in social space." Emotion, Space and Society, 3, 40-44.

Erkip, F. (2003). "The shopping mall as an emergent public space in Turkey." Environment and Planning A, 35, 1073-1093.

Erkip, F. \& Mugan, G. (2007). "The analysis of time-space interaction as a subjective measure of time-use: A case study in Ankara, Turkey.", paper presented at the IATUR Conference, Washington, DC, October 17-19.

Fyfe, N., Bannister, J. \& Kearns, A. (2006). “(In)civility and the city." Urban Studies, 43 (5/6), 853-861.

Held, N. (2015). "Comfortable and safe spaces? Gender, sexuality and 'race' in night-time leisure spaces." Emotion, Space and Society, 14, 33-42.

Hendry, L. B., Shucksmith, J., Love, J. G. \& Glendinning, A. (1993). Young people's leisure and lifestyles. London: Routledge.

Jackson, P. (1998). "Domesticating the street: the contested spaces of the high street and the mall." In N. Fyfe, (Ed.) Images of the street: Representation, experience and control in public space. (pp. 176-191) London: Routledge.

Konrad Adenauer Foundation (1999). Turkish youth 98: The silent majority highlighted. İstanbul: İstanbul Mülkiyeliler Foundation Social Research Center (IMV-SAM).

Lieberg, M. (1994). "Appropriating the city: Teenagers' use of public space." In S. J. Niery, M. S. Symes \& F. E. Brown (Eds.) The urban experience: A people-environment perspective (pp. 321-333) London: E \& FN Spon.

Loader, I., Girling, E. \& Sparks, R. (1998). "Narratives of decline: Youth, dis/order and community in an English 'middletown'." British Journal of Criminology, 38 (3), 388-403.

Malone, K. (2002). "Street life: Youth, culture and competing uses of public space." Environment \& Urbanization, 14 (2), 157-168.

Malone, K. \& Hasluck, L. (1998). "Geographies of exclusion: Young people's perceptions and use of public space." Australian Institute of Family Studies: Family Matters, 49, 20-26.

Matthews, H., Limb, M. \& Taylor, M. (2000). "The 'street as third space'." In S. L. Holloway \& G. Valentine, (Eds.) Children's geographies. (pp. 63-79) London: Routledge.

Mugan, G. (2009). Perception and experience of incivility by urban youth: A field survey in Ankara. (Unpublished Ph.D. Thesis). Ankara: Bilkent University.

Mugan, G. \& Erkip, F. (2009). "Discrimination against teenagers in the mall environment: A case from Ankara, Turkey." Adolescence. 44 (173), 209-232.

Ozdemir, A. \& Yilmaz, O. (2008). “Assessment of outdoor school 
environments and physical activity in Ankara's primary schools." Journal of Environmental Psychology, 28, 287-300.

Philips, T. \& Smith, P. (2006). "Rethinking urban incivility research: Strangers, Bodies and circulations." Urban Studies, $43(5 / 6), 879-901$.

Punch, S. (2000). "Children's strategies for creating play spaces." In S. L. Holloway \& G. Valentine (Eds.) Children's geographies. (pp. 48-62) London: Routledge.

Robin, M., Police, A. M. \& Couty, C. (2007). "Development of a scale of perceived environmetal annoyances in urban settings." Journal of Environmental Psychology, 27, 55-68.

Staeheli, L. A. \& Mitchell, D. (2006). "USA's destiny? Regulating space and creating community in American shopping malls." Urban Studies, 43 (5/6), 977-922.

TUIK [TURKSTAT] (2008). Zaman kullanım istatistikleri 2006. [Time-use statistics 2006]. Ankara: TUIK Matbaası.

Turhanoğlu, A. K. (2014). "Historical witness of the space for so- cial relations: Ankara Kızılay Square." The International Journal of Interdisciplinary Social and Community Studies, 8, 23-34.

Valentine, G. (2001). Social geographies: Space and society. Harlow: Prentice Hall.

Vanderbeck, R. M., \& Johnson, J. H. (2000). " "That's the only place where you can hang out": urban young people and the space of the mall." Urban Geography, 21(1), 5-25.

Wooley, H. (2006). "Freedom of the city: Contemporary issues and policy influences on children and young people's use of public open space in England." Children's Geographies, 4 (1), 45-59.

Yetkin, S. (2004). Urban culture and space relations: Sakarya Caddesi as an entertainment space in Ankara. (Unpublished Master Thesis). Ankara: METU.

Zaman (2003, May 21). "Sakarya Caddesi'nin çehresi değişiyor." [On-line] Available: <http://www.yapi.com.tr/Haberler/ haber_Detay_4414.html > 